\title{
Leucine-Rich Repeat Kinase 2 Modulates Neuroinflammation and Neurotoxicity in Models of Human Immunodeficiency Virus 1-Associated Neurocognitive Disorders
}

\author{
Jenna M. Puccini, ${ }^{1}$ Daniel F. Marker, ${ }^{1}$ Tim Fitzgerald, ${ }^{3}$ Justin Barbieri, ${ }^{1}$ Christopher S. Kim, ${ }^{1}$ Patrick Miller-Rhodes, ${ }^{1}$ \\ Shao-Ming Lu, ${ }^{1}$ Stephen Dewhurst, ${ }^{2}$ and Harris A. Gelbard ${ }^{1}$ \\ ${ }^{1}$ Center for Neural Development and Disease and ${ }^{2}$ Department of Microbiology and Immunology, University of Rochester, Rochester, New York 14642, and \\ ${ }^{3}$ Graduate Program in Medical Illustration, Rochester Institute of Technology, Rochester, New York 14623
}

\begin{abstract}
Leucine-rich repeat kinase 2 (LRRK2) is the single most common genetic cause of both familial and sporadic Parkinson's disease (PD), both of which share pathogenetic and neurologic similarities with human immunodeficiency virus 1 (HIV-1)-associated neurocognitive disorders (HAND). Pathologic LRRK2 activity may also contribute to neuroinflammation, because microglia lacking LRRK2 exposed to proinflammatory stimuli have attenuated responses. Because microglial activation is a hallmark of HIV-1 neuropathology, we have investigated the role of LRRK2 activation using in vitro and in vivo models of HAND. We hypothesize that LRRK2 is a key modulator of microglial inflammatory responses, which play a pathogenic role in both HAND and PD, and that these responses may cause or exacerbate neuronal damage in these diseases. The HIV-1 Tat protein is a potent neurotoxin produced during HAND that induces activation of primary microglia in culture and long-lasting neuroinflammation and neurotoxicity when injected into the CNS of mice. We found that LRRK2 inhibition attenuates Tat-induced pS935-LRRK2 expression, proinflammatory cytokine and chemokine expression, and phosphorylated $\mathrm{p} 38$ and Jun N-terminal kinase signaling in primary microglia. In our murine model, cortical Tat injection in LRRK2 knock-out (KO) mice results in significantly diminished neuronal damage, as assessed by microtubule-associated protein 2 (MAP2), class III $\beta$-tubulin TUJ1, synapsin-1, VGluT, and cleaved caspase-3 immunostaining. Furthermore, Tat-injected LRRK2 KO animals have decreased infiltration of peripheral neutrophils, and the morphology of microglia from these mice were similar to that of vehicle-injected controls. We conclude that pathologic activation of LRRK2 regulates a significant component of the neuroinflammation associated with HAND.
\end{abstract}

Key words: HIV-1; LRRK2; microglia; neuroinflammation; neurotoxicity; Parkinson's disease

\section{Introduction}

As the prevalence of human immunodeficiency virus 1 (HIV-1)associated neurocognitive disorders (HAND) increases in aging HIV-1-seropositive adults despite combined antiretroviral therapy (cART; Heaton et al., 2010; Cross et al., 2013; Hopcroft et al., 2013), we are forced to confront the intersection of HAND with other age-related neurodegenerative processes, including Parkinson's disease (PD). Although cART effectively limits virus repli-

Received Feb. 14, 2014; revised Feb. 16, 2015; accepted Feb. 24, 2015.

Author contributions: J.M.P., S.-M.L., S.D., and H.A.G. designed research; J.M.P., D.F.M., J.B., C.S.K., and P.M.-R. performed research; J.M.P., D.F.M., T.F., S.-M.L., S.D., and H.A.G. analyzed data; J.M.P., D.F.M., S.-M.L., S.D., and H.A.G. wrote the paper.

This work was funded by National Institutes of Health Grants P01 MH64570 (H.A.G., S.D.), R01 MH56838 (H.A.G.), R01 MH104147 (H.A.G.), UL1RR024160 (H.A.G.), P30 Al078494 (S.D., H.A.G.), T32 GM07356 (D.F.M.), T32 Al049815 (D.F.M.), F30 MH095664 (D.F.M.), and F32 MH099913 (J.M.P.) and the Geoffrey Waisdorp Pediatric Neurology Fund (H.A.G.). We sincerely thank Angela Stout for animal husbandry, Andrew B. West for assistance in experimental design, and Ann E. Casey and Richard P. Phipps for technical assistance with the Luminex Assay and use of their Luminex machine and Millipore software.

The authors declare no competing financial interests.

Correspondence should be addressed to Jenna M. Puccini, 601 Elmwood Avenue, Box 645, Center for Neural Development and Disease, Rochester, NY 14642. E-mail: jenna_puccini@urmc.rochester.edu.

DOI:10.1523/JNEUROSCI.0650-14.2015

Copyright $\odot 2015$ the authors $\quad 0270-6474 / 15 / 355271-13 \$ 15.00 / 0$ cation, it fails to stop the production of early viral proteins, such as the HIV-1 Tat protein (Kure et al., 1990; Anderson et al., 2002). In the CNS, infected monocytes and microglia harbor viral reservoirs that continue manufacturing Tat, which causes the production of neurotoxins, including cytokines and phospholipids, as well as neurotoxicity (Masliah et al., 1996; Ellis et al., 2007; Lu et al., 2011).

Given the ability of Tat to contribute to lasting neuroinflammation in the CNS, we have developed simplified in vitro and in vivo models that allow us to focus on how Tat alone alters complex aspects of microglia and neuronal crosstalk and function (Lu et al., 2011). In vitro, Tat-treated BV-2 microglia cells (Bocchini et al., 1992) become activated via changes in cytokine expression, process extension, and phagocytosis (Marker et al., 2012). In vivo, Tat injected into the murine cortex results in sustained neuroinflammation and neurotoxicity (Marker et al., 2013). To better understand microglial activation and how it contributes to HAND pathogenesis in our models, we have focused on leucine-rich repeat kinase 2 (LRRK2) inhibition, which has been implicated as a regulator of microglial activation during neuroinflammation (Greggio et al., 2012). 
LRRK2 is a large, multidomain protein that is expressed in immune cells, microglia, and neurons (Melrose et al., 2006; Seol, 2010). Mutations in LRRK2 account for the most common genetic cause of PD and primarily result in increased kinase activity (Zimprich et al., 2004; West et al., 2007; Gloeckner et al., 2010). Although such mutations have been shown to alter neurite length and neurogenesis, a causeand-effect relationship between LRRK2 and dopaminergic neuronal cell death has not been established (MacLeod et al., 2006; Winner et al., 2011). Thus, recent research has focused on the role of LRRK2 in microglia, because LRRK2 knockdown has been shown to attenuate microglial activation and LRRK2 knock-out (KO) transgenic mice exhibit decreased neuroinflammation after lipopolysaccharide (LPS) exposure (Moehle et al., 2012).

We have shown previously that a small-molecule LRRK2 kinase inhibitor (Deng et al., 2011) attenuates microglial activation in BV-2 microglial cells (Marker et al., 2012). Because these cells do not fully recapitulate intracellular signaling events attributable to oncogene transformation, we have now assessed the contribution of LRRK2 kinase activity in Tat-mediated activation of primary microglia. We found that Tat-induced cytokine and chemokine expression are attenuated during LRRK2 inhibition in vitro. We have extended these studies by examining the contribution of LRRK2 in vivo using our cortical Tat injection model in both wild-type (WT) and LRRK2 KO mice to analyze changes in neuronal and microglial morphology. We have found that Tat-exposed LRRK2 KO mice exhibit significantly ameliorated neurotoxicity and normalized microglial morphology, indicating that LRRK2 is a key mediator of synaptodendritic damage associated with HAND.

\section{Materials and Methods}

Primary microglia isolation and culture. Primary murine microglia isolated from postnatal day 2 CD1 mice were purchased from Creative Bioarray (catalog \#CSC-7843X). Cells were cultured using SuperCult Microglial Cell Medium (catalog \#CM-1082X; Creative Bioarray) at $37^{\circ} \mathrm{C}$ at $5 \% \mathrm{CO}_{2}$ for $2 \mathrm{~d}$ on poly-D-lysine (catalog \#P1149; Sigma)coated 12-well plates or on glass coverslips. We then treated the cells for $6 \mathrm{~h}$ in triplicate with saline vehicle control, $0.15 \mu \mathrm{g} / \mathrm{ml} \mathrm{HIV}-1$ Tat $_{86}$ from Joseph Steiner (National Institute of Neurological Disorders and Stroke, Division of Intramural Research, Translational Neuroscience Branch, Bethesda, MD), DMSO vehicle control, or the smallmolecule LRRK2 kinase inhibitors LRRK2-IN-1 from Millipore (catalog \#438193; $1 \mu \mathrm{M}$ working concentration) or GSK2578215A from Tocris Bioscience (catalog \#4629; $1 \mu \mathrm{M}$ working concentration) unless noted otherwise.

H
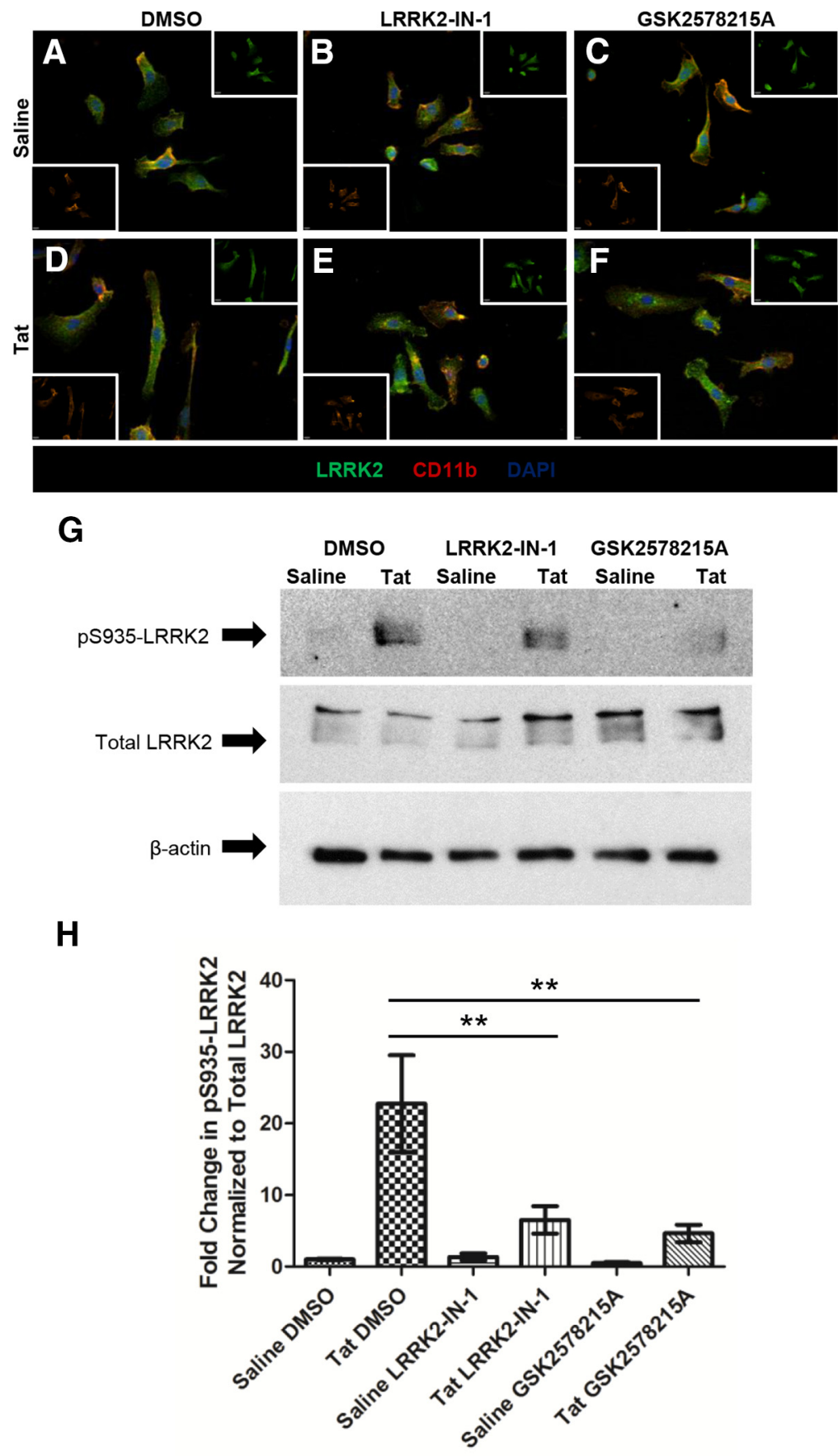

Figure 1. Effects of LRRK2 kinase inhibition in primary microglia. $A-F$, ICC of primary murine microglia for LRRK2 (green), CD11b (red), and DAPI (blue) after saline $(\boldsymbol{A}-\boldsymbol{C})$ or Tat $(\boldsymbol{D}-\boldsymbol{F})$ treatment with or without LRRK-IN-1 and GSK2578215A $(40 \times)$. $\boldsymbol{G}$, Western blot of pS935-LRRK2, total LRRK2, and $\beta$-actin protein levels $6 \mathrm{~h}$ after saline or Tat treatment with or without LRRK2-IN-1 and GSK2578215A. $\boldsymbol{H}$, Tat-induced pS935-LRRK2 is significantly decreased by LRRK2-IN-1 and GSK2578215A $\left({ }^{* *} p<0.01\right.$, one-way ANOVA with Newman-Keuls post hoc test).

Immunocytochemistry. We adapted our immunocytochemistry (ICC) protocol from Glynn and McAllister (2006). Briefly, we fixed the cells in a solution of $4 \%$ paraformaldehyde and $4 \%$ sucrose in $1 \times \mathrm{PBS}$ at $4^{\circ} \mathrm{C}$ for $10 \mathrm{~min}$. We then treated the fixed cells with $100 \mathrm{~mm}$ glycine in $1 \times \mathrm{PBS}$ and washed in $1 \times$ PBS for 5 min and permeabilized with $0.25 \%$ Triton X-100 (catalog \#H5142; Promega) in $1 \times$ PBS for 5 min. We prepared the primary antibodies in 3\% bovine serum albumin (BSA; catalog \#A329450G; Sigma) in $1 \times$ PBS at the following concentrations: rat anti-CD11b at 1:250 (catalog \#MCA711; Serotech) and rabbit anti-LRRK2 at 1:1000 (catalog \#3514-1; Epitomics). We incubated the fixed cells in the primary antibody solution for $1 \mathrm{~h}$ and then washed four times with $3 \%$ BSA and 

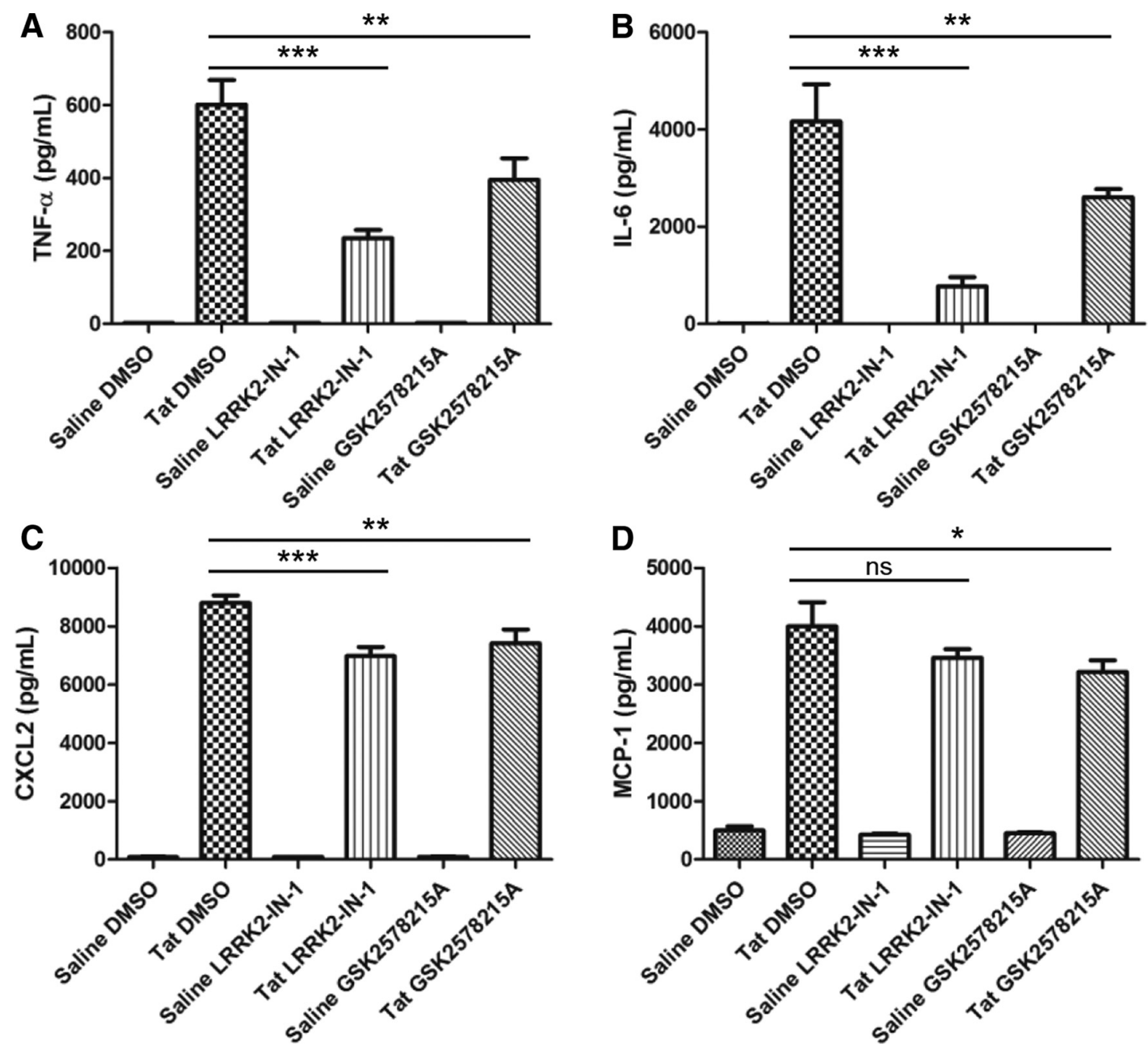

Figure 2. LRRK2 kinase inhibition attenuates Tat-induced proinflammatory cytokine and chemokine expression in primary microglia. Tat-induced expression of TNF- $\alpha(\boldsymbol{A})$, IL-6 $(\boldsymbol{B})$, and $C X C L 2$ (C) are significantly decreased by LRRK2-IN-1 and GSK2578215A, and Tat-induced expression of MCP-1 (D) is significantly decreased by GSK2578215A but not with LRRK2-IN-1 ( ${ }^{*} p<0.05,{ }^{* *} p<$ $0.01,{ }^{* * *} p<0.001$, one-way ANOVA with Newman-Keuls post hoc test).

$1 \times$ PBS for 5 min each. We incubated the cells in Alexa Fluor secondary antibodies (Invitrogen) in 3\% BSA in 1× PBS at 1:500 for $30 \mathrm{~min}$. We then washed the cells four times in $1 \times$ PBS for 5 min each and mounted them on glass slides using Prolong Gold with DAPI (catalog \#P36935; Life Technologies). We imaged the cultures with a Hamamatsu ORCA-ER camera on an Olympus BX-51 upright microscope with Quioptic Optigrid optical sectioning hardware. We controlled the acquisition with the Velocity 3DM software (PerkinElmer Life and Analytical Sciences).

Western blotting. We washed cells once with $1 \times$ PBS and scraped them directly into cell lysis buffer with protease and phosphatase inhibitors and lysed this cell suspension on ice with periodic vortexing for $30 \mathrm{~min}$. The cell lysates were then centrifuged at 13,000 rpm for $10 \mathrm{~min}$, and the supernatant was mixed with loading dye, heated at $70^{\circ} \mathrm{C}$ for $5 \mathrm{~min}$, and ran on a $4-15 \%$ SDS-PAGE gel (catalog \#456-1086; Bio-Rad) at $100 \mathrm{~V}$ for $1 \mathrm{~h}$. We transferred the gel onto a PVDF or nitrocellulose membrane at $100 \mathrm{~V}$ for $1 \mathrm{~h}$ on ice. We blocked membranes in $5 \%$ milk in $1 \times$ TBS for $1 \mathrm{~h}$ at room temperature with shaking. We washed membranes three times in $1 \times$ Tris-buffered saline with $0.1 \%$ Tween 20 (TBST). We applied primary antibodies overnight at $4^{\circ} \mathrm{C}$ with shaking at the following concentrations: rabbit anti-LRRK2 at 1:1000 (catalog \#3514-1; Epitomics), rabbit anti-pS935-LRRK2 at 1:1000 (catalog \#5099-1; Epitomics), rabbit anti-phosphorylated Jun N-terminal kinase (pJNK) at 1:1000 (catalog \#4668P; Cell Signaling Technology), mouse anti-pp38 at 1:1000 (catalog \#4511; Cell Signaling Technology), and $\beta$-actin at 1:500 (catalog \#sc-47778; Santa Cruz Biotechnology). We washed membranes three times in $1 \times$ TBST. We applied HRP-conjugated secondary antibody (GE Healthcare) at a concentration of 1:5000 in 5\% milk in $1 \times$ TBST for $1 \mathrm{~h}$ at room temperature with shaking. We washed membranes and applied ECL substrate (catalog \#32106; Pierce) for $5 \mathrm{~min}$. We exposed and developed membranes on film (catalog \#111-1681; Kodak).

Luminex multiplex ELISA. We collected $0.5 \mathrm{ml}$ of supernatant from control and treated primary microglia cells and froze the samples at $-80^{\circ} \mathrm{C}$. We used the Mouse Cytokine/Chemokine Magnetic Bead Panel (MCYTOMAG-70K; Millipore) to analyze the cytokine and chemokine concentration of the supernatants according to the instructions of the manufacturer and used the following bead-coated antibodies in our analysis: tumor necrosis factor- $\alpha$ (TNF- $\alpha$; MCYTNFA-MAG), interleukin 6 (IL-6; MCYIL6-MAG), monocyte chemoattractant protein 1 (MCP-1; MCYMCP1-MAG), and chemokine macrophage inflammatory protein $2 \alpha$ (CXCL2; MMIP2-MAG). Briefly, we added $25 \mu$ lof beads with $25 \mu \mathrm{l}$ of supernatant or mouse cytokine or chemokine standard (MXM80702), which were serially diluted to $10,000,2000,400,80,16$, and $3.2 \mathrm{pg} / \mathrm{ml}$ and incubated with shaking overnight at $4^{\circ} \mathrm{C}$. We then added $25 \mu \mathrm{l}$ of detection antibodies (MXM1070-1) to each well for $1 \mathrm{~h}$ with shaking at room temperature. Next, we added $25 \mu$ of streptavidin-phycoerythrin (L-SAPE3) to each well for $30 \mathrm{~min}$ with shaking at room temperature. We ran the plate on a Millipore Luminex 200 machine with xPONENT 3.1 software. Using the standard curves for the given cytokine or chemokine, 


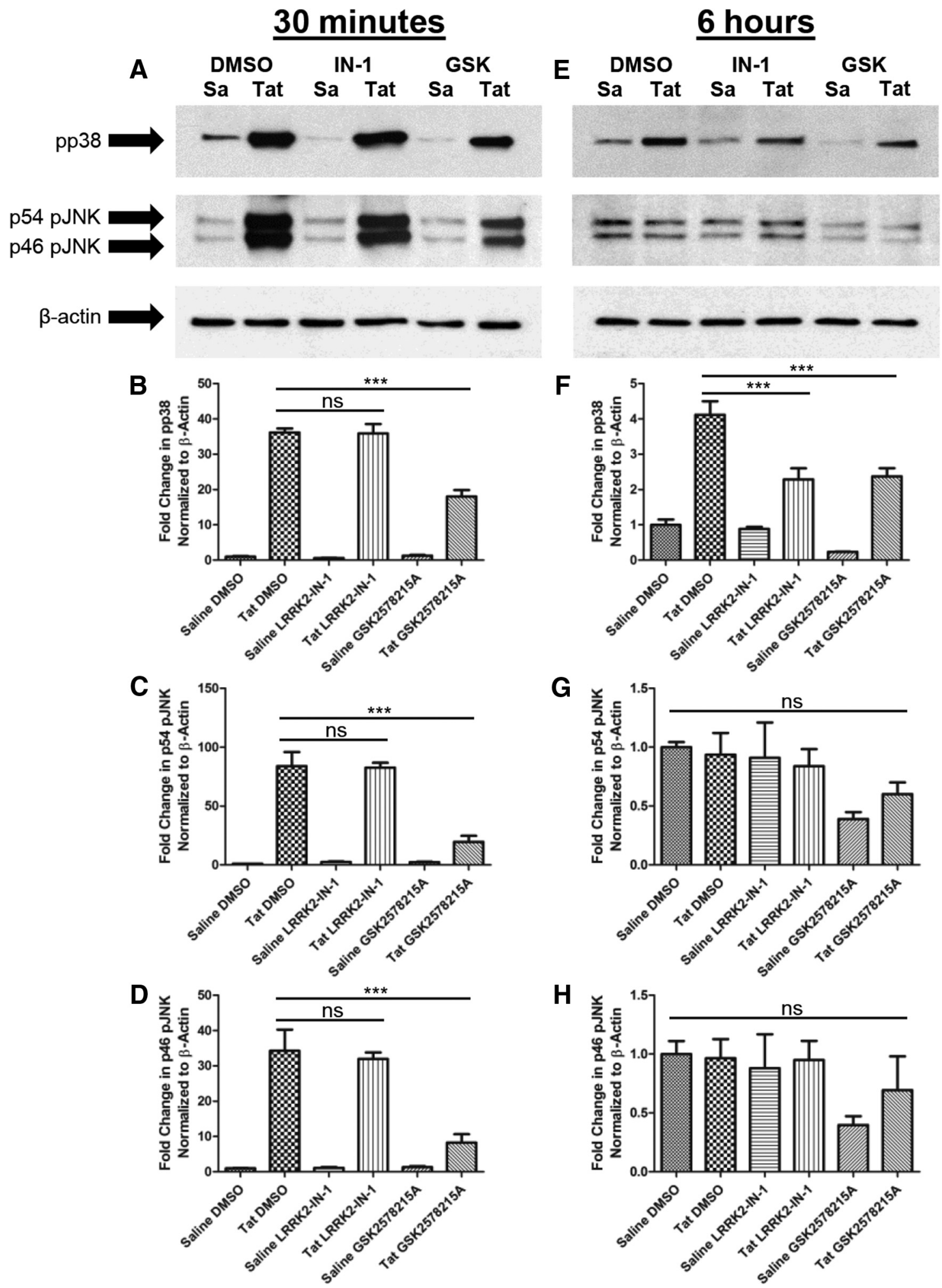

Figure 3. LRRK2 kinase inhibition reduces $\mathrm{p} 38$ and JNK signaling in Tat-treated primary microglia. Western blot of pp38, p54 pJNK, p46 pJNK, and $\beta$-actin protein levels 30 min $(\boldsymbol{A})$ and $6 \mathrm{~h}(\boldsymbol{E})$ after saline (Sa) or Tat treatment with or without LRRK2-IN-1 (IN-1) and GSK2578215A (GSK). B-D, GSK2578215A, but not LRRK2-IN-1, significantly inhibits Tat-induced pp38, p54 pJNK, and p46 pJNK 30 min after treatment. $\boldsymbol{F}-\boldsymbol{H}$, LRRK2-IN-1 and GSK2578215A significantly inhibit Tat-induced pp38 $6 \mathrm{~h}$ after treatment, but no change in p54 pJNK or p46 pJNK is observed (*** $p<0.01$, one-way ANOVA with Newman-Keuls post hoc test).

we obtained absolute concentrations for the various experimental conditions for all analytes measured.

In vivo Tat stereotactic injection. We performed stereotactic injection in WT C57BL/6 and LRRK2 exon $41 \mathrm{KO}$ mice (Hinkle et al., 2012) of either sex with $3 \mu \mathrm{l}$ of sterile PBS or $3 \mu \mathrm{l}$ of $3 \mu \mathrm{g} / \mu \mathrm{l} \mathrm{HIV-1}$ Tat $_{101}$ from
Philip Ray (University of Kentucky, Lexington, KY), in sterile PBS as described previously (Marker et al., 2010, 2013; Lu et al., 2011). We used seven animals per treatment group, four of which were processed by vibratome sectioning and three of which were processed by cryostat sectioning. We injected at the coordinates $1.0 \mathrm{~mm}$ posterior to bregma, 1.0 

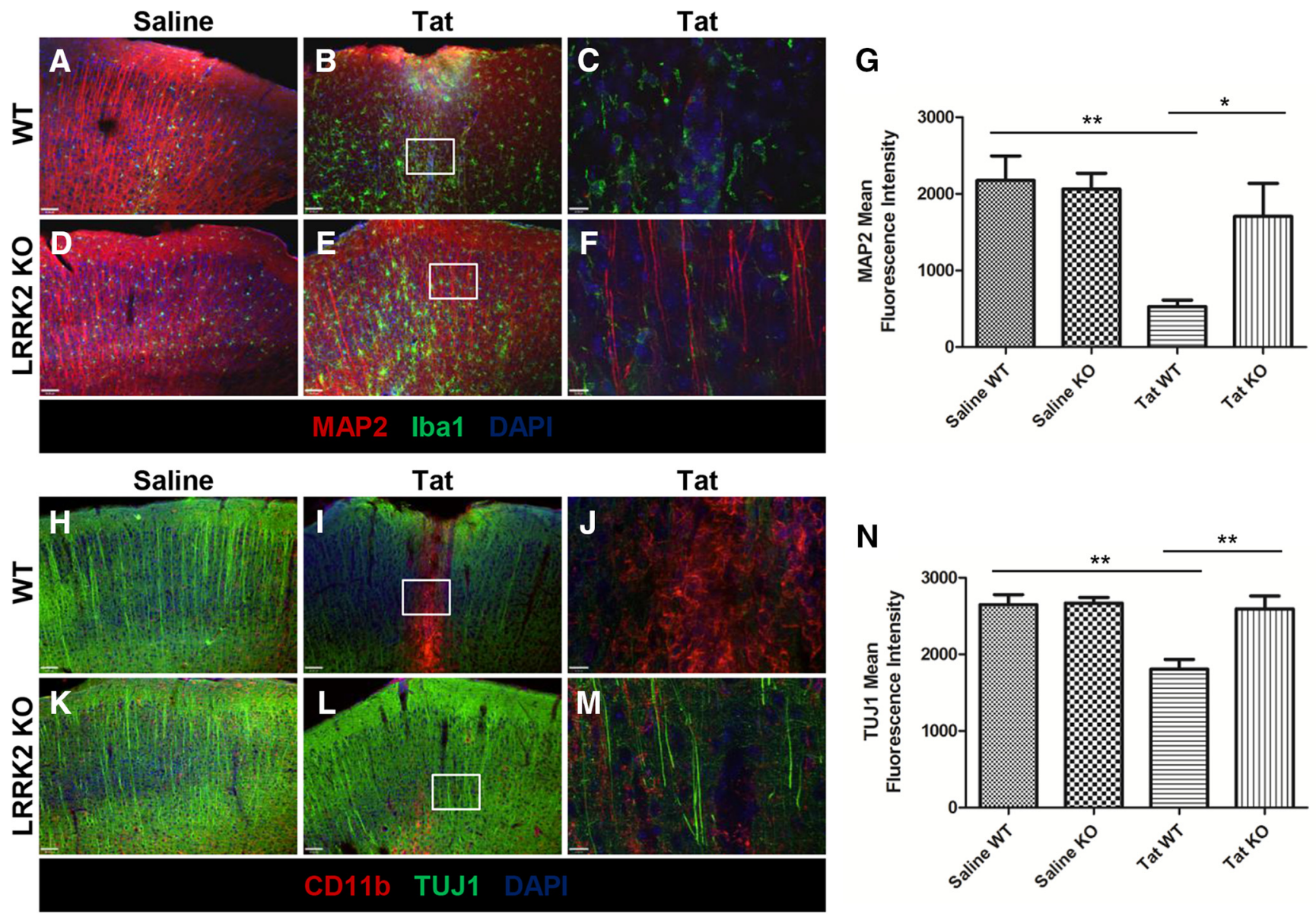

Figure 4. LRRK2 KO prevents neurotoxicity and diminishes microglial activation after in vivo cortical Tat injection. $A-G, I H C$ for MAP2 (red), Iba1 (green), and DAPI (blue) in saline control animals $(\boldsymbol{A}, 10 \times ; \boldsymbol{D}, 10 \times)$, Tat-treated WT mice $(\boldsymbol{B}, 10 \times ; \boldsymbol{C}, 60 \times)$, and Tat-treated $\mathrm{KO}$ mice $(\boldsymbol{E}, 10 \times ; \boldsymbol{F}, 60 \times) . \mathbf{G}$, LRRK2 K0 significantly increases MAP2 expression in Tat-treated animals. $\boldsymbol{H}-\boldsymbol{N}$, IHC for CD11b (red), TUJ1 (green), and DAPI (blue) in saline control animals $(\boldsymbol{H}, 10 \times ; \boldsymbol{K}, 10 \times)$, Tat-treated WT mice $(\boldsymbol{I}, 10 \times ; \boldsymbol{J}, 60 \times)$, and Tat-treated K0 mice $(\boldsymbol{L}, 10 \times ; \boldsymbol{M}, 60 \times) . \boldsymbol{N}, \mathbf{L R R K 2} \mathrm{KO}$ significantly increases TUJ1 expression in Tat-treated animals ( ${ }^{*} p<0.05,{ }^{* *} p<0.01$, one-way ANOVA with Newman-Keuls post hoc test). Scale bars: $A, B, D, E, H, I, K, L, 60 \mu \mathrm{m} ; C, F, J, M, 11 \mu \mathrm{m}$.

$\mathrm{mm}$ lateral left to the midline, and $0.7 \mathrm{~mm}$ ventral to the pial surface. We used a 35 gauge needle with a $10 \mu \mathrm{l}$ NanoFil syringe (World Precision Instruments) coated with Sigmacote (SL-2; Sigma) to prevent Tat from adhering to the walls of the needle and syringe. We injected at a flow rate of $80 \mathrm{nl} / \mathrm{min}$ using a microsyringe pump (Micro4; World Precision Instruments) to minimize volume and pressure-related injury from the injection.

Immunohistochemistry. We killed animals at $7 \mathrm{~d}$ after treatment by pentobarbital overdose and transcardially perfused them with periodatelysine-3.5\% paraformaldehyde (PLP) fixative (McLean and Nakane, 1974). We postfixed the brains in 3.5\% PLP overnight and then stored them in $1 \times \mathrm{PBS}$ at $4^{\circ} \mathrm{C}$. We cut the brains into $40-\mu \mathrm{m}$-thick coronal sections on a vibratome (V1000; Leica) and stored them in a cryoprotectant mixture of 30\% PEG300 (catalog \#PX1286A-2; EMD), 30\% glycerol (catalog \#56-81-5; Alfa Aesa), 20\% 0.1 M phosphate buffer, and 20\% $\mathrm{dd}_{2} \mathrm{O}$ at $-20^{\circ} \mathrm{C}$. For frozen sections, we added $5 \%$ sucrose to the PLP fixative and stored them overnight at $4^{\circ} \mathrm{C}$, then $15 \%$ sucrose in $1 \times \mathrm{PBS}$ overnight at $4^{\circ} \mathrm{C}$, and then $30 \%$ sucrose in $1 \times$ PBS overnight at $4^{\circ} \mathrm{C}$. Next, we flash-froze the brains on dry ice for $15 \mathrm{~min}$ and cut $40-\mu \mathrm{m}$-thick coronal sections on a cryostat. We performed free-floating section immunohistochemistry (IHC) as described previously (Lu et al., 2011). We washed the sections three times for $30 \mathrm{~min}$ in PBS to remove the cryoprotectant for vibratome-cut sections. For frozen sections only, we performed antigen unmasking in citrate buffer (catalog \#H-3300; Vector Laboratories) at $37^{\circ} \mathrm{C}$ for $30 \mathrm{~min}$. We prepared the primary antibody mixture in $1.5 \%$ BSA (catalog \#A3294; Sigma), 3\% normal goat serum (catalog \#S1000; Vector Laboratories), $0.5 \%$ Triton X-100 (catalog \#H5142; Promega), and $1.8 \% \mathrm{NaCl}$ in $1 \times \mathrm{PBS}$. We used the following antibodies in these experiments: rabbit anti-ionized calcium-binding adapter molecule 1 (Iba1) at 1:1000 (catalog \#019-19741; Wako), mouse anti-microtubule-associated protein 2 (MAP2) at 1:500 (catalog \#M4403; Sigma), rat anti-7/4 at 1:1000 (catalog \#ab53457; Abcam), rabbit anti-synapsin-1 at 1:400 (catalog \#5297; Cell Signaling Technology), guinea pig anti-VGluT at 1:1000 (catalog \#AB5905; Millipore), rat antiCD11b at 1:400 (catalog \#MCA711; Serotech), mouse anti-NeuN at 1:1000 (catalog \#MAB377; Millipore), rabbit anti-class III $\beta$-tubulin (TUJ1) at 1:1000 (catalog \#PRB-435; Covance), rabbit anti-cleaved caspase- 3 at 1:100 (catalog \#9661; Cell Signaling Technology), and rabbit anti-LRRK2 at 1:50 (catalog \#3514-1; Epitomics). We incubated the sections in the primary antibody mixture for $3 \mathrm{~d}$ at room temperature with agitation and an additional $5 \mathrm{~d}$ at $4^{\circ} \mathrm{C}$ with agitation if the staining included MAP2 or synapsin-1. We then washed the sections three times for $30 \mathrm{~min}$ in $1 \times$ PBS with $1.8 \% \mathrm{NaCl}$ and prepared the Alexa Fluorconjugated antibodies (1:500; Invitrogen) in the same staining mixture described above. We incubated the sections in secondary antibody overnight at room temperature with agitation. Finally, we washed the sections three times with $1 \times$ PBS, mounted the sections on slides, and coverslipped the slides with number 1.5 cover glass and Prolong Gold mounting agent with DAPI. Imaging was performed as described for ICC.

Amira image analysis. We used the Amira image analysis software to determine the morphologic characteristics of Iba1-positive microglia imaged from IHC as described previously (Marker et al., 2013). We imported single-channel z-stacks of $20 \times$ fields of microglia and ran the median noise reduction function. We then segmented and labeled the individual microglia via manually guided thresholding. We used the center line tree algorithm function to create skeleton trees of the labeled 


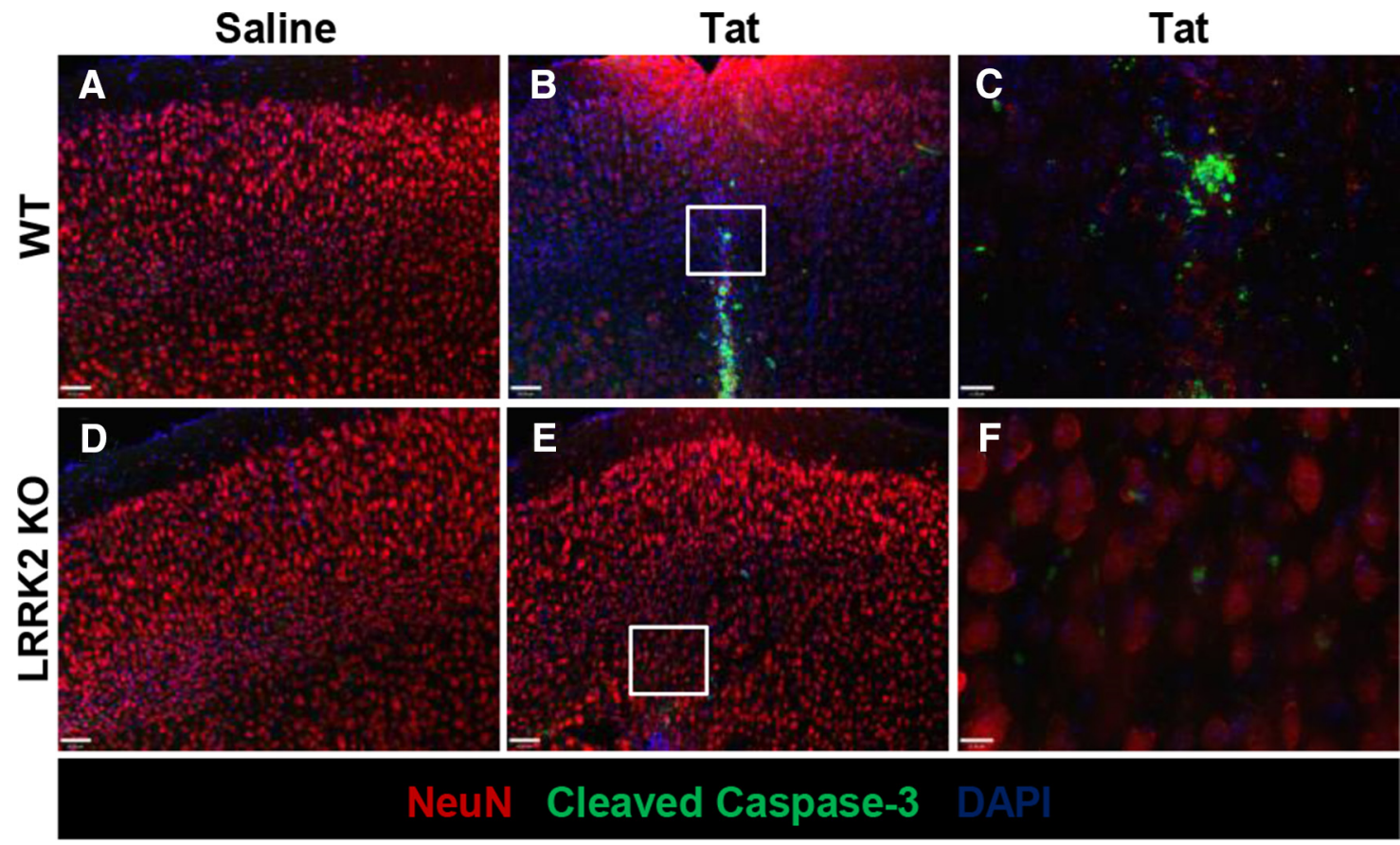

G

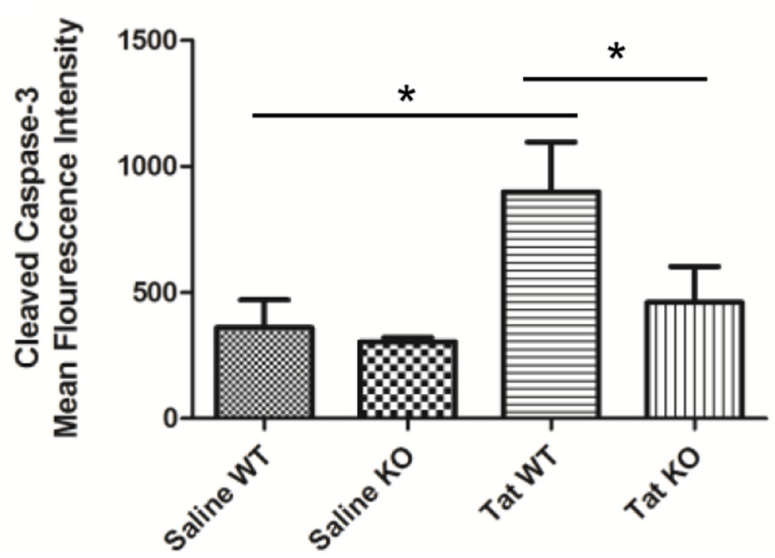

Figure 5. LRRK2 KO decreases cleaved caspase-3 expression at the Tat injection site. $\boldsymbol{A}-\boldsymbol{F}$, IHC for NeuN (red), cleaved caspase-3 ( $g r e e n)$, and DAPI (blue) in saline control animals ( $\boldsymbol{A}, 10 \times ; \boldsymbol{D}$, $10 \times)$, Tat-treated WT mice $(\boldsymbol{B}, 10 \times ; \boldsymbol{C}, 60 \times)$, and Tat-treated K0 mice $(\boldsymbol{E}, 10 \times ; \boldsymbol{F}, 60 \times) . \boldsymbol{G}$, LRRK2 K0 significantly decreases cleaved caspase-3 expression in Tat-treated animals $\left(^{*} p<0.05\right.$, one-way ANOVA with Newman-Keuls post hoc test). Scale bars: $A, B, D, E, 60 \mu \mathrm{m} ; \boldsymbol{C}, \boldsymbol{F}, 11 \mu \mathrm{m}$.

microglia. Finally, we obtained process number and length measurements from the skeleton trees with the spatial graph statistics function.

Statistics. We performed all of our statistical analysis using GraphPad Prism statistical software (GraphPad Software). We defined significance as $p<0.05$. For experiments with more than two experimental conditions at a single time point or a single condition with multiple time points, we used the one-way ANOVA with Newman-Keuls post hoc tests.

\section{Results}

LRRK2 kinase inhibition decreases Tat-induced pS935-LRRK2 expression in primary microglia

Our group has described previously LRRK2 protein expression and kinase inhibition after Tat exposure in the BV-2 microglia cell line (Marker et al., 2012). However, literature reports have suggested discordant cytokine responses to proinflammatory stimuli in these cells (Horvath et al., 2008; Henn et al., 2009; Stansley et al., 2012), prompting us to extend our studies to primary microglial cultures. We found that CD11b-positive (Fig. 1A-F, red signal) primary microglial cells expressed
LRRK2 by both ICC (Fig. 1A-F, green signal) and Western blotting (Fig. $1 G$ ). After Tat treatment, we observed altered morphology and a statistically significant increase in pS935LRRK2 expression (Fig. $1 D, H$ ) that was attenuated by the LRRK2 kinase inhibitors LRRK2-IN-1 and GSK2578215A (Fig. $1 E, F, H)$.

LRRK2 kinase inhibition decreases Tat-induced cytokine and chemokine expression

We found that LRRK2-IN-1 and GSK2578215A attenuated Tatinduced protein expression of the cytokine TNF- $\alpha$ (Fig. $2 A$ ), the cytokine IL-6 (Fig. 2B), and the chemokine CXCL2 (Fig. 2C). Tat-induced expression of the chemokine MCP-1 was attenuated by GSK2578215A but not LRRK2-IN-1 (Fig. 2D). These chemokines and cytokines are found in the CSF of HAND patients and contribute to immune activation and infiltration, as well as neuronal damage (Tyor et al., 1992; Buscemi et al., 2007; Xing et al., 2009; Yuan et al., 2013). 

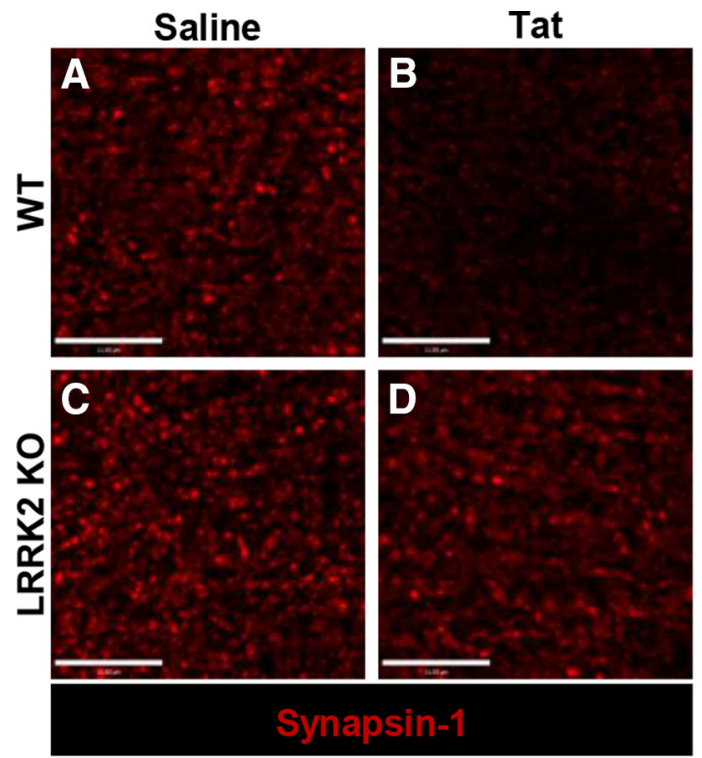

\section{Synapsin-1}

Saline
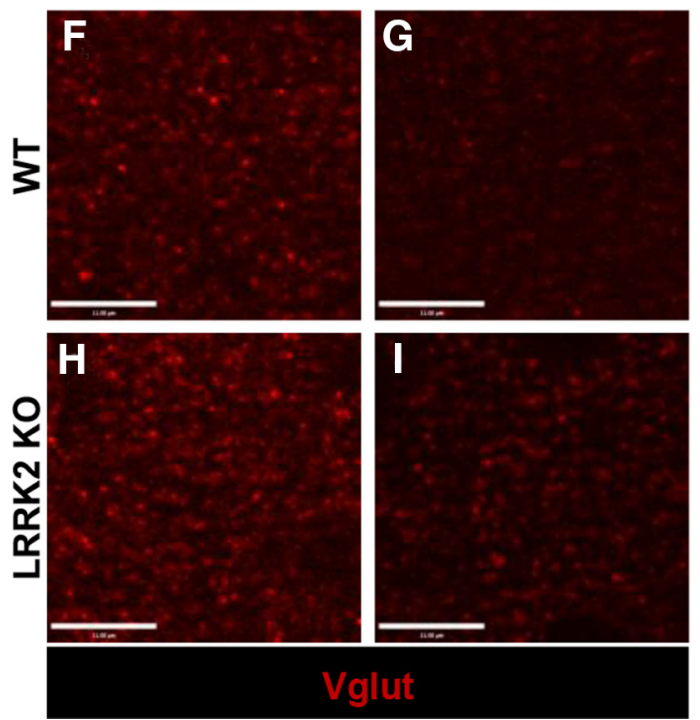

Tat

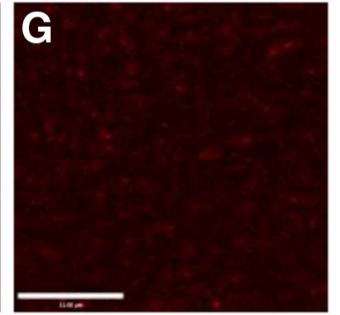

$\mathbf{J}$

$\mathbf{E}$
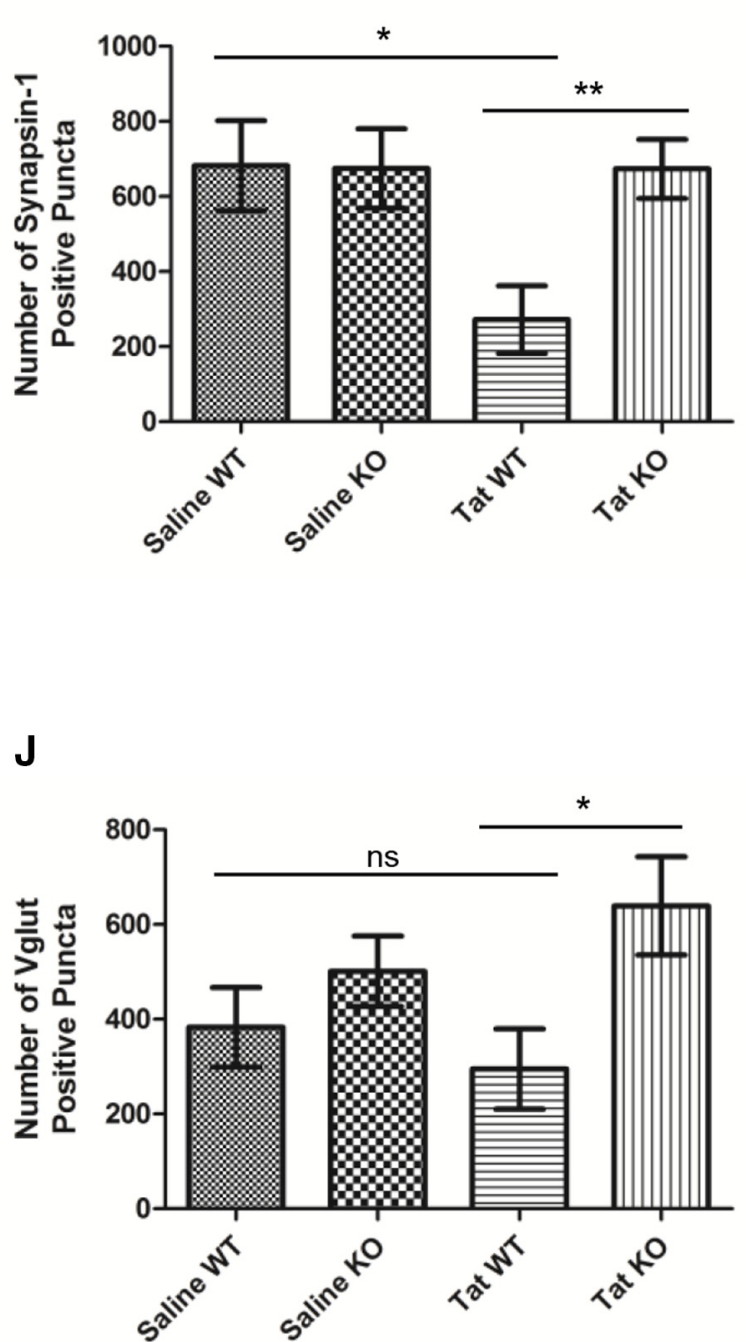

Figure 6. Synaptic vesicle puncta are preserved in Tat-injected LRRK2 KO mice. IHC for synapsin-1 (red; $\boldsymbol{A}-\boldsymbol{E}$ ) and VGluT (red; $\boldsymbol{F}-\boldsymbol{J}$ ) was performed, and two $60 \times$ images were taken at the injection site per animal and analyzed using the Velocity software program, which revealed that Tat-injected WT mice have significantly fewer synaptic puncta $(\boldsymbol{B}, \boldsymbol{E}, \boldsymbol{G}, \boldsymbol{J})$ compared with Tat-injected LRRK2 KO mice $(\boldsymbol{D}, \boldsymbol{I})$ and saline control animals $(\boldsymbol{A}, \boldsymbol{C}, \boldsymbol{F}, \boldsymbol{H})\left({ }^{*} p<0.05,{ }^{* *} p<0.01\right.$, one-way ANOVA with Newman-Keuls post hoc test). Scale bars, $11 \mu \mathrm{m}$.

pp38 and JNK signaling are altered by LRRK2 kinase inhibition after Tat treatment

We then analyzed mitogen-activated protein kinase (MAPK) signaling, which has been shown to be altered by LRRK2 (Kim et al., 2012). At $30 \mathrm{~min}$ after treatment, we found that Tat-induced pp38 and the p54 and p46 species of pJNK were significantly decreased by GSK2578215A but not LRRK2-IN-1 in primary microglia (Fig. $3 A-D$ ). At $6 \mathrm{~h}$ after treatment, we found that Tatinduced pp38 was significantly decreased by both LRRK2-IN-1 and GSK2578215A, whereas pJNK was not altered by Tat treatment (Fig. 3E-H).

LRRK2 KO is neuroprotective and attenuates inflammation in our in vivo HAND model

Next, we examined the effects of Tat exposure in vivo in LRRK2 $\mathrm{KO}$ mice and found that these mice had markedly diminished neurotoxicity as assessed by MAP2 (Fig. $4 A-F$, red signal) and
TUJ1 (Fig. 4H-M, green signal) immunostaining $7 \mathrm{~d}$ after injection. Although dendritic MAP2 and TUJ1 staining is maintained in saline-treated controls (Fig. $4 A, D, H, K$ ), it is essentially absent $7 \mathrm{~d}$ after Tat treatment in WT mice (Fig. $4 B, C, I, J$ ) but was preserved in Tat-treated LRRK2 KO mice (Fig. 4E, F, L, M). These results were quantified and showed a significant decrease in MAP2 and TUJ1 mean fluorescence intensity in Tat-injected animals but was preserved at near-control levels in Tat-injected LRRK2 KO mice (Fig. 4G,N). Furthermore, we observed that Tat-injected LRRK2 KO mice exhibited decreased neuroinflammation compared with Tat-injected WT mice, as measured qualitatively by immunostaining for microglial Iba1 (Fig. 4A-F, green signal) and microglial and peripheral leukocyte marker CD11b (Fig. 4H-M, red signal). Both Ibal and CD11b immunostaining were increased in Tat-injected WT animals (Fig. $4 B, C, I, J$ ) compared with saline controls (Fig. $4 A, D, H, K$ ) and Tat-injected 
LRRK2 KO mice (Fig. 4E, F, L, M). Quantitation of microglia morphology in our model is accessed in Figure 9.

Increased cleaved caspase- 3 expression is observed at the Tat injection site in WT mice

To further assess damage at the Tat injection site, we performed immunostaining for cleaved caspase-3 (Fig. 5A-F, green signal), an indicator of apoptosis and microglial activation, in our murine model (Burguillos et al., 2011). We found that Tat-injected WT mice had cleaved caspase- 3 immunostaining at the Tat injection site (Fig. $5 B, C$ ), but very little staining was observed in saline controls (Fig. 5A,D) and Tat-injected LRRK2 KO mice (Fig. $5 E, F$ ). We quantified mean fluorescence intensity for cleaved caspase- 3 in the immediate vicinity of the needle track and found a significant increase in Tat WT mice but not in LRRK2 $\mathrm{KO}$ animals (Fig. 5G). We also costained with NeuN (Fig. 5A-F, red signal), which labels neuronal nuclei, and found decreased $\mathrm{NeuN}$ immunostaining in Tat-injected WT mice (Fig. $5 B, C$ ), with preserved NeuN staining present in saline controls (Fig. $5 A, D$ ) and Tat-injected LRRK2 $\mathrm{KO}$ animals (Fig. $5 E, F)$.

Synaptic puncta loss is prevented after Tat injection in LRRK2 KO mice

To further assess integrity of presynaptic nerve terminals, we performed immunostaining for synapsin-1, expressed in the cytoplasm of synaptic vesicles (Fig. $6 A-D$, red signal), and VGluT, a marker of presynaptic terminals (Fig. $6 F-I$, red signal). We quantified the number of synapsin-1-positive puncta (Fig. 6E) and VGluT-positive puncta (Fig. $6 \mathrm{~J}$ ) in these fields and found that Tat-treated LRRK2 KO mice have a significant increase in puncta when compared with Tat-treated WT mice.

Infiltrating 7/4-positive neutrophils are decreased in the CNS of Tat-injected LRRK2 KO animals

Peripheral immune cell recruitment in the Tat-injected CNS is a well described occurrence in our animal model (Lu et al., 2011; Marker et al., 2013). As such, we evaluated the number of neutrophils infiltrating the CNS $7 \mathrm{~d}$ after Tat injection by immunostaining for $7 / 4$ antigen, which labels neutrophils and immature monocytes found in the bone marrow (Hirsch and Gordon, 1983; Fig. $7 A-F$, green signal). Very few infiltrating cells were observed in saline controls (Fig. $7 A, D$ ), but a large influx of $7 / 4-$ immunopositive cells were found in Tat-treated WT animals (Fig. $7 B$ ) compared with Tat-treated LRRK2 KO animals (Fig. $7 E)$. To further define these cells as granulocytes, we examined high-magnification images of our Tat-treated mice (Fig. $7 C, F$ ) and found that these cells demonstrated a multi-lobed nuclear morphology consistent with neutrophils in the vast majority of 7/4-positive cells (Fig. 7C,F, white arrows). We counted the number of 7/4-positive cells per treatment group and found that Tattreated WT mice have a significant increase in the number of recruited 7/4-positive cells compared with saline controls, but this recruitment was significantly decreased in Tat-treated LRRK2 KO mice (Fig. $7 G$ ). We also show that brain homogenates from our global LRRK2 KO mice do not express LRRK2 protein (Fig. $7 H$ )

\section{LRRK2 is not expressed in infiltrating 7/4-positive} neutrophils in our Tat injection model

To assess whether the increase in neutrophils in Tat-injected WT mice was correlated with LRRK2 expression in these cells, we costained for LRRK2 (Fig. 8A-H, green signal) with the neutrophil marker $7 / 4$ (Fig. $8 B, D, F, H$, red signal) and the microglia and peripheral leukocyte marker CD11b (Fig. $8 A, C, E$, G, red signal). Although we observed LRRK2 expression in CD11bpositive cells after Tat injection in WT mice (Fig. 8A), LRRK2 was not expressed in 7/4-positive cells in these animals (Fig. 8B). Additionally, LRRK2 was not expressed in CD11b- or 7/4positive cells in saline WT mice (Fig. $8 C, D$ ) or in LRRK2 $\mathrm{KO}$ animals (Fig. $8 E-H$ ). To further define LRRK2 expression in Tat WT mice, we examined high-magnification and single-channel images (Fig. $8 I-P$ ). We found that LRRK2 (Fig. $8 M, N$ ) was expressed in CD11b-positive cells (Fig. $8 \mathrm{~K}, I$, white arrows) but not in 7/4-positive cells (Fig. $8 L$, J, white arrowheads).

\section{LRRK2 KO mice exhibit normalized microglia morphology} after Tat exposure

To gain additional insight into the complex morphologic changes in microglia observed in WT and LRRK2 KO mice $7 \mathrm{~d}$ after Tat 

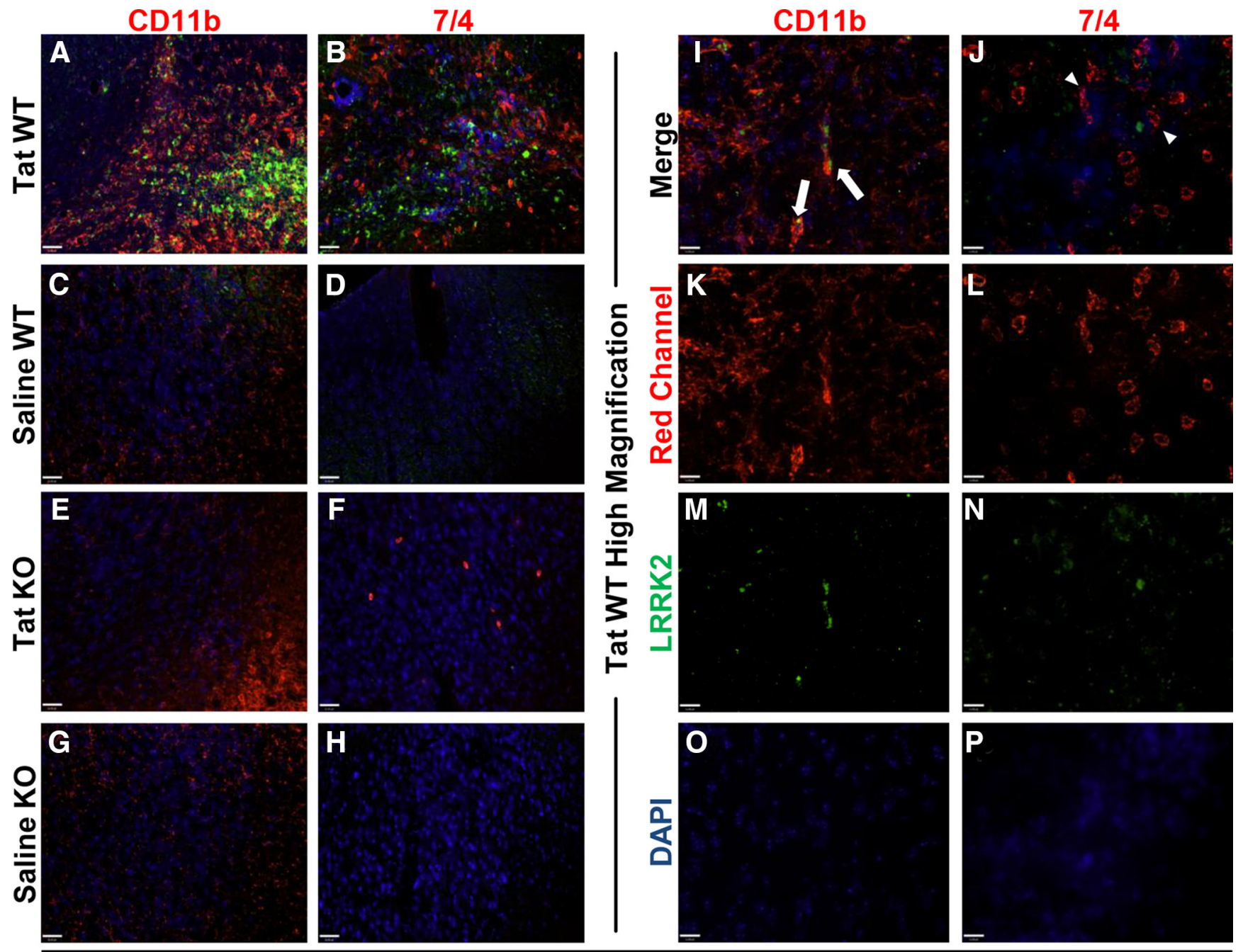

\section{LRRK2}

Figure 8. LRRK2 is not expressed in neutrophils in the CNS of Tat-injected mice. $\boldsymbol{A}-\boldsymbol{H}$, IHC for CD11b (red, left column), 7/4 (red, right column), LRRK2 (green), and DAPI (blue) in WT Tat-injected animals $(\boldsymbol{A}, \boldsymbol{B})$, WT saline-injected animals $(\boldsymbol{C}, \boldsymbol{D})$, LRRK2 KO Tat-injected animals $(\boldsymbol{E}, \boldsymbol{F})$, and LRRK2 K0 saline-injected animals $(\boldsymbol{G}, \boldsymbol{H})(20 \times)$. I-P, IHC for CD11b (red, left column), $7 / 4$ (red, right column), LRRK2 (green), and DAPI (blue) in high-magnification $(60 \times)$ merge $(\boldsymbol{I}, \boldsymbol{J})$ and single-channel images $(\boldsymbol{K}-\boldsymbol{P})$ for WT Tat-injected animals $(\boldsymbol{I}$, white arrows depict CD11b-and LRRK2-positive cells; J, white arrowheads depict 7/4-postive LRRK2-negative cells). Scale bars: A-H, $32 \mu \mathrm{m} ; \boldsymbol{I}-\boldsymbol{P}, 11 \mu \mathrm{m}$.

exposure (Fig. 4), we used Amira image analysis software to analyze microglia from our immunohistochemical data. We identified the injection site by the needle track and analyzed the section $\sim 320 \mu \mathrm{m}$ away in all cases. We have included MAP2 immunostaining (Fig. 9A,E,I,M, single channel) of these sections, in which MAP2 signal was intact in Tat-injected LRRK2 KO mice (Fig. 9N) and saline controls (Fig. $9 B, F$ ) but essentially absent in Tat-treated WT animals (Fig. 9J), which is consistent with our previous data showing neurotoxicity (Fig. 4) and increased cleaved caspase-3 expression (Fig. 5) in Tat-injected WT mice. In these same sections, we found increased neuroinflammation as qualitatively measured by immunostaining for Iba1positive microglia (Fig. 9A,E,I,M, single channel). Tat-treated WT animals (Fig. 9I) exhibited increased Ibal immunostaining but not saline controls (Fig. 9A,E) or Tat-treated LRRK2 KO mice (Fig. 9M). Thus, areas of inflammation and microglial activation (Iba1, green signal) are observed in the presence of neuronal damage (MAP2, red signal) in Tat-treated WT mice (Fig. $9 K$, merged with DAPI) but not saline controls (Fig. 9C,G, merged with DAPI) or Tat-treated LRRK2 KO mice (Fig. 9O, merged with DAPI). To further analyze microglia morphology in these sections, we imported single-channel $20 \times$ Ibal images into the Amira program in which individual microglia were labeled and converted into three-dimensional skeletons to quantitate parameters of microglial processes (i.e., number and length). We determined that Tat-treated LRRK KO microglia (Fig. 9Q,R) were more similar to microglia in saline control animals as opposed to activated microglia in Tat-injected WT mice. Specifically, microglia from Tat-treated WT mice (Fig. 9L) had significantly fewer processes and shorter processes compared with saline controls (Fig. 9D,H). In contrast, microglia from Tattreated LRRK2 KO mice (Fig. 9P) had significantly more and longer processes than Tat-treated WT mice (Fig. 9Q,R).

\section{Discussion}

LRRK2 is a target with increasing importance in the study of neurodegenerative disease, yet much is still unknown regarding its biochemistry and signaling properties. Although activity of the kinase domain is linked to PD pathogenesis, its targets, aside from itself, have been difficult to elucidate (Gandhi et al., 2009; 

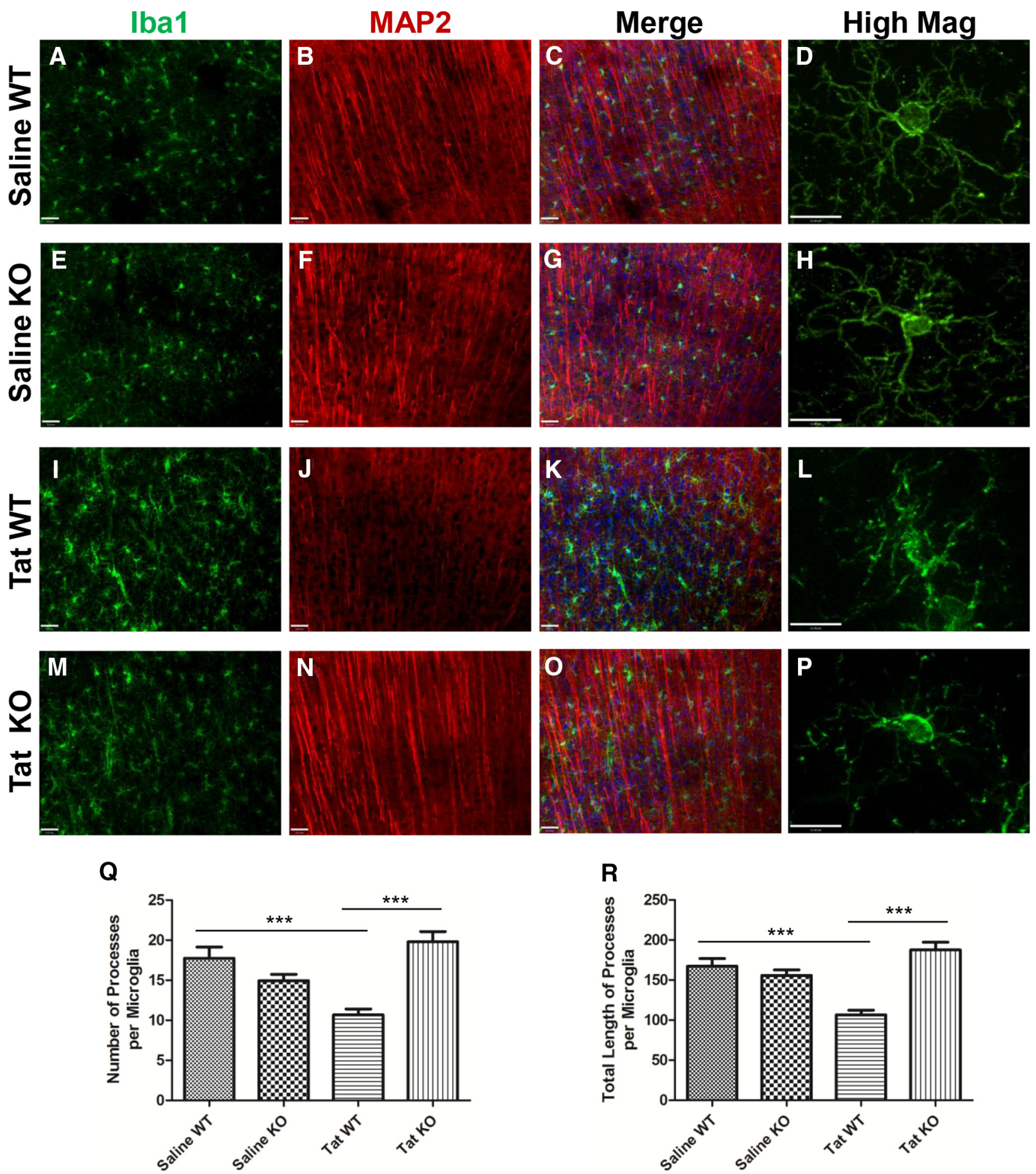

Figure 9. LRRK2 KO normalizes microglia morphology in Tat-injected mice. $A-P$, IHC for single-channel lba1 (green; $A, E, I, M, 20 \times ; D, H, L, P, 60 \times), M A P 2($ red; $B, F, J, N, 20 \times)$, and merged images with DAPI (blue; $\boldsymbol{C}, \mathbf{G}, \boldsymbol{K}, \mathbf{0}, 20 \times$ ) was performed. $\mathbf{Q}-\boldsymbol{R}$, Images as $20 \times$ taken at the injection were labeled and skeletonized using Amira software and microglia from Tat-injected $L R R K 2 \mathrm{KO}$ mice $(\boldsymbol{M}-\boldsymbol{P})$ have significantly more processes $(\boldsymbol{Q})$ and longer processes $(\boldsymbol{R})$ compared with Tat-injected WT mice $(\boldsymbol{I}-\boldsymbol{L}){ }^{* * *} \boldsymbol{p}<0.001$, one-way ANOVA with Newman-Keuls post hoc test). Scale bars: $A-C, E-G, I-K, M-0,32 \mu \mathrm{m} ; \mathbf{D}, \mathbf{H}, \mathbf{L}, \mathbf{P}, 11 \mu \mathrm{m}$.

Dzamko et al., 2010). For example, LRRK2 is known to interact with the 14-3-3 binding protein, but the significance of this interaction in disease is unclear (Nichols et al., 2010; Li et al., 2011), although 14-3-3 proteins have been implicated recently as a biomarker for HAND (Morales et al., 2012). In view of some of the similarities between HAND and PD, our experiments were designed to better understand the contribution of LRRK2 activation to neurotoxicity and inflammation in the context of HIV-1 infection in the CNS. Thus, our data have unveiled LRRK2 as an important mediator of neuroinflamma- 


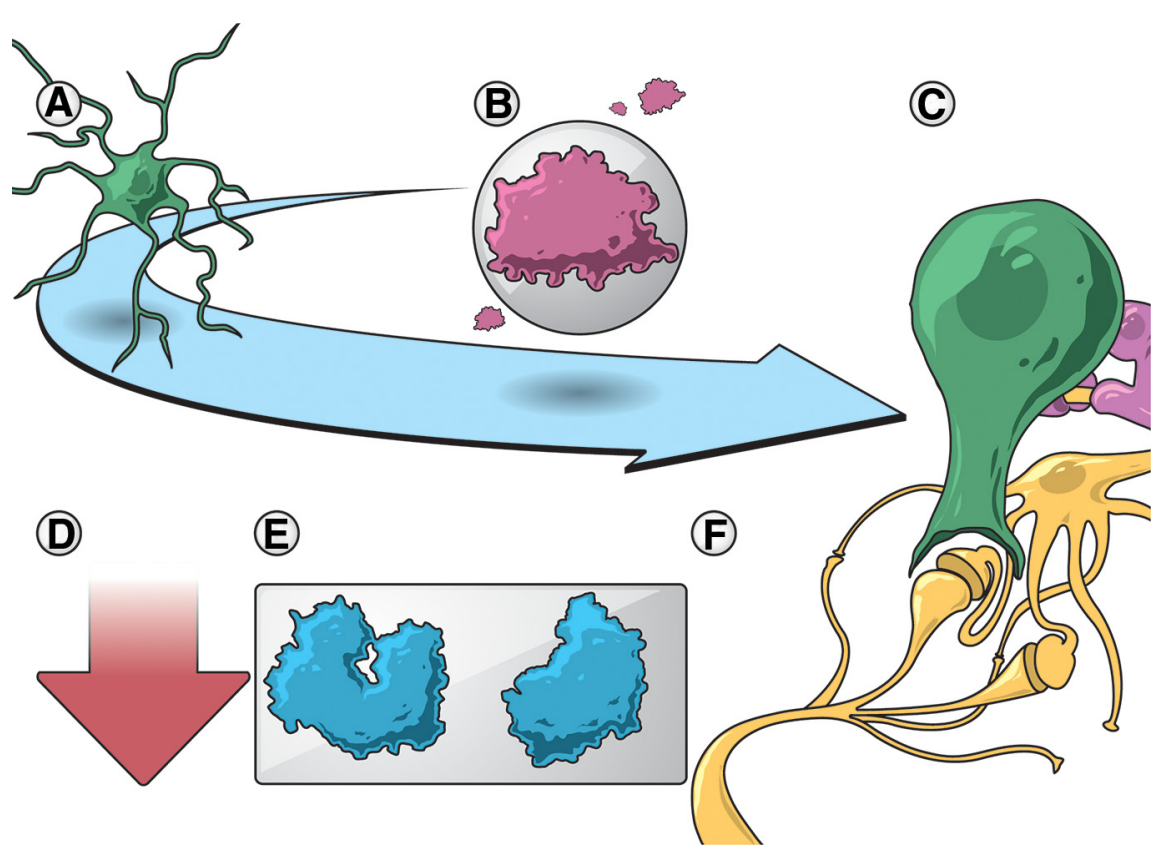

Figure 10. Tat-induced changes in microglia morphology and function. When microglia $(\boldsymbol{A})$ become exposed to the HIV-1 Tat protein $(\boldsymbol{B})$, they retract their processes and become more amoeboid in shape $(\boldsymbol{C}$, release proinflammatory cytokines $(\boldsymbol{E})$, and can phagocytose neuronal elements $(\boldsymbol{F})$. $\boldsymbol{D}$, This Tat-induced microglial activation is decreased by LRRK2 kinase inhibition.

and using a lentiviral-based knockdown model versus an LRRK2 inhibitor. Furthermore, we observed a 35 -fold increase in pp38, an 84-fold increase in p54 pJNK, and a 30 -fold increase in p56 pJNK at 30 min after Tat treatment compared with a fourfold increase in pp38 and no fold change in p54 or p46 pJNK at $6 \mathrm{~h}$ after Tat treatment. These findings denote that these changes in MAPK signaling occur rapidly after Tat treatment and are diminished over time. Additionally, it has been shown that LRRK2 can phosphorylate MAPK kinase (MKK) 3/6 and MKK4/7 in vitro (Gloeckner et al., 2009), indicating that the effects of LRRK2 may occur upstream, but Kim et al. did not detect any changes in MKK3/6 in LRRK2 knockdown of BV-2 cells at early time points.

Recent research has shown that neutrophils can mediate neurotoxicity during neuroinflammatory disorders (Allen et al., 2012). Furthermore, neutrophil chemoattractants, such as IL-8, have been linked to Tat and HIV infection in the CNS (Jones et al., 1998; Hofman et al., 1999; Zheng et al., 2008). We have shown

tion and neuronal damage in our in vitro and in vivo models of HAND.

We have shown previously that the small-molecule LRRK2 inhibitor LRRK2-IN-1 (Deng et al., 2011) inhibits Tat-induced microglial activation in the BV-2 murine microglial cell line (Marker et al., 2012). However, contemporary studies have indicated that LRRK2-IN-1 has significant off-target effects, because it has been shown to cause anti-inflammatory effects in LRRK2 KO cells (Liu et al., 2014; Luerman et al., 2014). Thus, we have performed our studies in primary microglia using both LRRK2IN-1 and GSK2578215A (Reith et al., 2012), a more selective small-molecule LRRK2 kinase inhibitor. Although both inhibitors attenuated Tat-induced pS935-LRRK2 expression (Fig. 1), some notable differences were observed in cytokine and chemokine expression (Fig. 2) and MAP kinase signaling (Fig. 3). In Figure 2, the significance of LRRK2-IN-1 attenuation $(p<0.001)$ was greater than that of GSK2578215A $(p<0.01)$ for Tatinduced TNF- $\alpha$, IL- 6 , and CXCL2, which may be an indication of off-target effects of LRRK2-IN-1. Although both GSK2578215A and LRRK2-IN-1 decreased Tat-induced MCP-1, only the decrease with GSK2578215A was significant $(p<0.05)$, demonstrating that MCP-1 may be less susceptible to off-target effects. In Figure 3, GSK2578215A, but not LRRK2-IN-1, significantly decreased pp38 and pJNK species 30 min after treatment, although both inhibitors significantly decreased pp38, but not pJNK, species $6 \mathrm{~h}$ after treatment. This result may point toward kinetic differences between the inhibitors.

Our laboratories have shown previously an increase in MAPK signaling $30 \mathrm{~min}$ after Tat treatment in human macrophages (Sui et al., 2006). Additionally, Kim et al. (2012) has reported that LPS-induced pp38 is decreased in LRRK2 knockdown BV-2 microglia cells between 15 and 60 min after treatment but not pJNK or pERK. We have found that both Tat-induced pp38 and pJNK are attenuated by GSK2578215A 30 min after treatment in primary microglia. These results may highlight differences between primary murine microglia and BV-2 cells, LPS and Tat induction, that the murine chemokine CXCL2, an IL-8 homolog known to induce neutrophil chemotaxis, is significantly increased after Tat treatment and had the greatest increase of the cytokines and chemokines we observed (Fig. 2). These data correlate with our animal model, in which we found increased 7/4-positive neutrophil recruitment $7 \mathrm{~d}$ after cortical Tat injection (Fig. 7). Interestingly, LRRK2 inhibition in vitro attenuated CXCL2 expression, and Tat-injected LRRK2 KO mice had fewer 7/4-positive neutrophils. Furthermore, 7/4-positive neutrophils in the CNS of Tatinjected WT mice did not express LRRK2 (Fig. 8), indicating that the increased infiltration was not attributable to intrinsic LRRK2 expression. Because we used mice with a global deletion of LRRK2 (Hinkle et al., 2012), we cannot identify which cell type is responsible for this phenomenon. Thus, future studies will focus on what cell type, whether peripheral or resident to the CNS, may be mediating LRRK2-regulated neuroinflammation (Greggio et al., 2012).

The most striking result from this study is the significant neuroprotection we observed in Tat-injected LRRK2 KO mice (Figs. 4-6). Our group has shown previously substantial neurotoxicity lasting up to $28 \mathrm{~d}$ in Tat-injected animals (Lu et al., 2011; Marker et al., 2013). In this study, we observed increased cleaved caspase- 3 immunostaining at the Tat injection site in WT animals and neurotoxicity in the surrounding parenchyma, whereas Tatinjected LRRK2 KO mice had healthy neuronal architecture in these same areas. However, these mice have an LRRK2 deletion for all cells, thus obfuscating which cell type mediates neuroprotection. Although we observed preservation of neuronal architecture using MAP2, TUJ1, and NeuN immunostaining (Figs. 4, 5), a decrease in infiltrating granulocytes (Fig. 7), and changes in microglia morphology (Fig. 9), we do not understand the causeand-effect paradigm in our in vivo model. Future studies focused on conditional genetic deletion may prove valuable in addressing these concerns.

Microglia have been shown recently to play an active role in the healthy and diseased brain, actively participating in synapse 
pruning and clearing pathogens (Nimmerjahn et al., 2005; Tremblay et al., 2011). Very recently, we have demonstrated that microglia/perivascular macrophages extend filopodia in response to Tat, which may be the first step in phagocytosis of synaptic elements (Tremblay et al., 2013). We are very interested in microglial-neuronal interactions as mediators of neurotoxicity and have shown previously that Tat-treated BV-2 cells phagocytose primary axons in microfluidic coculture (Marker et al., 2012). More specifically, these interactions have been implicated in microglial phagocytosis of dying neurons (Brown and Neher, 2012), a phenomenon we have observed after Tat injection into the cortex (Marker et al., 2013; Tremblay et al., 2013). In this study, we expand on these findings in vivo, showing that microglia from Tat-treated LRRK2 KO mice have an increased number of processes and longer processes $7 \mathrm{~d}$ after injection compared with Tat injection alone and were not significantly different in morphology from saline-injected control animals (Fig. 9). Thus, our data suggest that the morphology of microglia in Tat-injected LRRK2 KO mice appear more like those of control injected animals at this time point, indicating that changes in microglial activation status may influence neuronal integrity. Furthermore, both proinflammatory and anti-inflammatory phagocytosis (i.e., Tatmediated increases in microglial phagocytosis of synaptic elements secondary to inflammation or "binge eating" vs microglial phagocytosis of damaged synaptic elements to limit additional indiscriminate attack on functional synapses) may be occurring in our model, thus complicating the interactions between these cell types. As yet, we are unable to experimentally distinguish between these phenomena. We summarize these changes in microglial morphology and neuronal interactions after exposure to Tat in Figure 10.

Future research will focus on determining which cell type or types are responsible for these results by generating a microglialspecific LRRK2 KO animal using the CX3C chemokine receptor 1-Cre recombinase estrogen receptor strategy (Wolf et al., 2013), utilizing both intravital microscopy and microfluidic culture techniques to establish the relative contributions of macrophages/microglia and neutrophils in synaptodendritic damage. In conclusion, we propose that LRRK2 plays an essential role in regulating neuroinflammation and neurotoxicity in our HAND models.

\section{References}

Allen C, Thornton P, Denes A, McColl BW, Pierozynski A, Monestier M, Pinteaux E, Rothwell NJ, Allan SM (2012) Neutrophil cerebrovascular transmigration triggers rapid neurotoxicity through release of proteases associated with decondensed DNA. J Immunol 189:381-392. CrossRef Medline

Anderson E, Zink W, Xiong H, Gendelman HE (2002) HIV-1-associated dementia: a metabolic encephalopathy perpetrated by virus-infected and immune-competent mononuclear phagocytes. J Acquir Immune Defic Syndr 31 [Suppl 2]:S43-S54.

Bocchini V, Mazzolla R, Barluzzi R, Blasi E, Sick P, Kettenmann H (1992) An immortalized cell line expresses properties of activated microglial cells. J Neurosci Res 31:616-621. CrossRef Medline

Brown GC, Neher JJ (2012) Eaten alive! Cell death by primary phagocytosis: "phagoptosis." Trends Biochem Sci 37:325-332. CrossRef Medline

Burguillos MA, Deierborg T, Kavanagh E, Persson A, Hajji N, GarciaQuintanilla A, Cano J, Brundin P, Englund E, Venero JL, Joseph B (2011) Caspase signalling controls microglia activation and neurotoxicity. Nature 472:319-324. CrossRef Medline

Buscemi L, Ramonet D, Geiger JD (2007) Human immunodeficiency virus type-1 protein Tat induces tumor necrosis factor-alpha-mediated neurotoxicity. Neurobiol Dis 26:661-670. CrossRef Medline

Cross HM, Combrinck MI, Joska JA (2013) HIV-associated neurocognitive disorders: antiretroviral regimen, central nervous system penetration ef- fectiveness, and cognitive outcomes. S Afr Med J 103:758-762. CrossRef Medline

Deng X, Dzamko N, Prescott A, Davies P, Liu Q, Yang Q, Lee JD, Patricelli MP, Nomanbhoy TK, Alessi DR, Gray NS (2011) Characterization of a selective inhibitor of the Parkinson's disease kinase LRRK2. Nat Chem Biol 7:203-205. CrossRef Medline

Dzamko N, Deak M, Hentati F, Reith AD, Prescott AR, Alessi DR, Nichols RJ (2010) Inhibition of LRRK2 kinase activity leads to dephosphorylation of Ser(910)/Ser(935), disruption of 14-3-3 binding and altered cytoplasmic localization. Biochem J 430:405-413. CrossRef Medline

Ellis R, Langford D, Masliah E (2007) HIV and antiretroviral therapy in the brain: neuronal injury and repair. Nat Rev Neurosci 8:33-44. CrossRef Medline

Gandhi PN, Chen SG, Wilson-Delfosse AL (2009) Leucine-rich repeat kinase 2 (LRRK2): a key player in the pathogenesis of Parkinson's disease. J Neurosci Res 87:1283-1295. CrossRef Medline

Gloeckner CJ, Schumacher A, Boldt K, Ueffing M (2009) The Parkinson disease-associated protein kinase LRRK2 exhibits MAPKKK activity and phosphorylates MKK3/6 and MKK4/7, in vitro. J Neurochem 109:959968. CrossRef Medline

Gloeckner CJ, Boldt K, von Zweydorf F, Helm S, Wiesent L, Sarioglu H, Ueffing M (2010) Phosphopeptide analysis reveals two discrete clusters of phosphorylation in the N-terminus and the Roc domain of the Parkinson-disease associated protein kinase LRRK2. J Proteome Res 9:1738-1745. CrossRef Medline

Glynn MW, McAllister AK (2006) Immunocytochemistry and quantification of protein colocalization in cultured neurons. Nat Protoc 1:12871296. CrossRef Medline

Greggio E, Civiero L, Bisaglia M, Bubacco L (2012) Parkinson's disease and immune system: is the culprit LRRKing in the periphery? J Neuroinflammation 9:94. CrossRef Medline

Heaton RK, Clifford DB, Franklin DR Jr, Woods SP, Ake C, Vaida F, Ellis RJ, Letendre SL, Marcotte TD, Atkinson JH, Rivera-Mindt M, Vigil OR, Taylor MJ, Collier AC, Marra CM, Gelman BB, McArthur JC, Morgello S, Simpson DM, McCutchan JA, et al. (2010) HIV-associated neurocognitive disorders persist in the era of potent antiretroviral therapy: CHARTER Study. Neurology 75:2087-2096. CrossRef Medline

Henn A, Lund S, Hedtjärn M, Schrattenholz A, Pörzgen P, Leist M (2009) The suitability of BV2 cells as alternative model system for primary microglia cultures or for animal experiments examining brain inflammation. ALTEX 26:83-94. Medline

Hinkle KM, Yue M, Behrouz B, Dächsel JC, Lincoln SJ, Bowles EE, Beevers JE, Dugger B, Winner B, Prots I, Kent CB, Nishioka K, Lin WL, Dickson DW, Janus CJ, Farrer MJ, Melrose HL (2012) LRRK2 knockout mice have an intact dopaminergic system but display alterations in exploratory and motor co-ordination behaviors. Mol Neurodegener 7:25. CrossRef Medline

Hirsch S, Gordon S (1983) Polymorphic expression of a neutrophil differentiation antigen revealed by monoclonal antibody $7 / 4$. Immunogenetics 18:229-239. CrossRef Medline

Hofman FM, Chen P, Incardona F, Zidovetzki R, Hinton DR (1999) HIV-1 tat protein induces the production of interleukin- 8 by human brainderived endothelial cells. J Neuroimmunol 94:28-39. CrossRef Medline

Hopcroft L, Bester L, Clement D, Quigley A, Sachdeva M, Rourke SB, Nixon SA (2013) "My body's a 50 year-old but my brain is definitely an 85 year-old": exploring the experiences of men ageing with HIV-associated neurocognitive challenges. J Int AIDS Soc 16:18506. CrossRef Medline

Horvath RJ, Nutile-McMenemy N, Alkaitis MS, Deleo JA (2008) Differential migration, LPS-induced cytokine, chemokine, and NO expression in immortalized BV-2 and HAPI cell lines and primary microglial cultures. J Neurochem 107:557-569. CrossRef Medline

Jones M, Olafson K, Del Bigio MR, Peeling J, Nath A (1998) Intraventricular injection of human immunodeficiency virus type 1 (HIV-1) tat protein causes inflammation, gliosis, apoptosis, and ventricular enlargement. J Neuropathol Exp Neurol 57:563-570. CrossRef Medline

Kim B, Yang MS, Choi D, Kim JH, Kim HS, Seol W, Choi S, Jou I, Kim EY, Joe EH (2012) Impaired inflammatory responses in murine lrrk2-knockdown brain microglia. PLoS One 7:e34693. CrossRef Medline

Kure K, Lyman WD, Weidenheim KM, Dickson DW (1990) Cellular localization of an HIV-1 antigen in subacute AIDS encephalitis using an improved double-labeling immunohistochemical method. Am J Pathol 136: 1085-1092. Medline 
Li X, Wang QJ, Pan N, Lee S, Zhao Y, Chait BT, Yue Z (2011) Phosphorylation-dependent 14-3-3 binding to LRRK2 is impaired by common mutations of familial Parkinson's disease. PLoS One 6:e17153. CrossRef Medline

Liu Z, Galemmo RA Jr, Fraser KB, Moehle MS, Sen S, Volpicelli-Daley LA, DeLucas LJ, Ross LJ, Valiyaveettil J, Moukha-Chafiq O, Pathak AK, Ananthan S, Kezar H, White EL, Gupta V, Maddry JA, Suto MJ, West AB (2014) Unique functional and structural properties of the LRRK2 protein ATP-binding pocket. J Biol Chem 289:32937-32951. CrossRef Medline

Lu SM, Tremblay MÈ, King IL, Qi J, Reynolds HM, Marker DF, Varrone JJ, Majewska AK, Dewhurst S, Gelbard HA (2011) HIV-1 Tat-induced microgliosis and synaptic damage via interactions between peripheral and central myeloid cells. PLoS One 6:e23915. CrossRef Medline

Luerman GC, Nguyen C, Samaroo H, Loos P, Xi H, Hurtado-Lorenzo A, Needle E, Stephen Noell G, Galatsis P, Dunlop J, Geoghegan KF, Hirst WD (2014) Phosphoproteomic evaluation of pharmacological inhibition of leucine-rich repeat kinase 2 reveals significant off-target effects of LRRK-2-IN-1. J Neurochem 128:561-576. CrossRef Medline

MacLeod D, Dowman J, Hammond R, Leete T, Inoue K, Abeliovich A (2006) The familial Parkinsonism gene LRRK2 regulates neurite process morphology. Neuron 52:587-593. CrossRef Medline

Marker DF, Tremblay ME, Lu SM, Majewska AK, Gelbard HA (2010) A thin-skull window technique for chronic two-photon in vivo imaging of murine microglia in models of neuroinflammation. J Vis Exp pii:2059. CrossRef Medline

Marker DF, Puccini JM, Mockus TE, Barbieri J, Lu SM, Gelbard HA (2012) LRRK2 kinase inhibition prevents pathological microglial phagocytosis in response to HIV-1 Tat protein. J Neuroinflammation 9:261. CrossRef Medline

Marker DF, Tremblay MÈ, Puccini JM, Barbieri J, Gantz Marker MA, Loweth CJ, Muly EC, Lu SM, Goodfellow VS, Dewhurst S, Gelbard HA (2013) The new small-molecule mixed-lineage kinase 3 inhibitor URMC-099 is neuroprotective and anti-inflammatory in models of human immunodeficiency virus-associated neurocognitive disorders. J Neurosci 33:999810010. CrossRef Medline

Masliah E, Ge N, Mucke L (1996) Pathogenesis of HIV-1 associated neurodegeneration. Crit Rev Neurobiol 10:57-67. CrossRef Medline

McLean IW, Nakane PK (1974) Periodate-lysine-paraformaldehyde fixative. A new fixation for immunoelectron microscopy. J Histochem Cytochem 22:1077-1083. CrossRef Medline

Melrose H, Lincoln S, Tyndall G, Dickson D, Farrer M (2006) Anatomical localization of leucine-rich repeat kinase 2 in mouse brain. Neuroscience 139:791-794. CrossRef Medline

Moehle MS, Webber PJ, Tse T, Sukar N, Standaert DG, DeSilva TM, Cowell RM, West AB (2012) LRRK2 inhibition attenuates microglial inflammatory responses. J Neurosci 32:1602-1611. CrossRef Medline

Morales D, Skoulakis EC, Acevedo SF (2012) 14-3-3s are potential biomarkers for HIV-related neurodegeneration. J Neurovirol 18:341-353. CrossRef Medline

Nichols RJ, Dzamko N, Morrice NA, Campbell DG, Deak M, Ordureau A, Macartney T, Tong Y, Shen J, Prescott AR, Alessi DR (2010) 14-3-3 binding to LRRK2 is disrupted by multiple Parkinson's disease-associated mutations and regulates cytoplasmic localization. Biochem J 430:393404. CrossRef Medline

Nimmerjahn A, Kirchhoff F, Helmchen F (2005) Resting microglial cells are highly dynamic surveillants of brain parenchyma in vivo. Science 308: 1314-1318. CrossRef Medline

Reith AD, Bamborough P, Jandu K, Andreotti D, Mensah L, Dossang P, Choi HG, Deng X, Zhang J, Alessi DR, Gray NS (2012) GSK2578215A; a potent and highly selective 2-arylmethyloxy-5-substitutent-N-arylbenzamide LRRK2 kinase inhibitor. Bioorg Med Chem Lett 22:5625-5629. CrossRef Medline

Seol W (2010) Biochemical and molecular features of LRRK2 and its pathophysiological roles in Parkinson's disease. BMB Rep 43:233-244. CrossRef Medline

Stansley B, Post J, Hensley K (2012) A comparative review of cell culture systems for the study of microglial biology in Alzheimer's disease. J Neuroinflammation 9:115. CrossRef Medline

Sui Z, Fan S, Sniderhan L, Reisinger E, Litzburg A, Schifitto G, Gelbard HA, Dewhurst S, Maggirwar SB (2006) Inhibition of mixed lineage kinase 3 prevents HIV-1 Tat-mediated neurotoxicity and monocyte activation. J Immunol 177:702-711. CrossRef Medline

Tremblay MÈ, Stevens B, Sierra A, Wake H, Bessis A, Nimmerjahn A (2011) The role of microglia in the healthy brain. J Neurosci 31:16064-16069. CrossRef Medline

Tremblay MÈ, Marker DF, Puccini JM, Mully EC, Lu SM, Gelbard HA (2013) Ultrastructure of microglia-synapse interactions in the HIV-1 Tat-injected murine central nervous system. Commun Integr Biol 6:e27670. CrossRef Medline

Tyor WR, Glass JD, Griffin JW, Becker PS, McArthur JC, Bezman L, Griffin DE (1992) Cytokine expression in the brain during the acquired immunodeficiency syndrome. Ann Neurol 31:349-360. CrossRef Medline

West AB, Moore DJ, Choi C, Andrabi SA, Li X, Dikeman D, Biskup S, Zhang Z, Lim KL, Dawson VL, Dawson TM (2007) Parkinson's diseaseassociated mutations in LRRK2 link enhanced GTP-binding and kinase activities to neuronal toxicity. Hum Mol Genet 16:223-232. CrossRef Medline

Winner B, Melrose HL, Zhao C, Hinkle KM, Yue M, Kent C, Braithwaite AT, Ogholikhan S, Aigner R, Winkler J, Farrer MJ, Gage FH (2011) Adult neurogenesis and neurite outgrowth are impaired in LRRK2 G2019S mice. Neurobiol Dis 41:706-716. CrossRef Medline

Wolf Y, Yona S, Kim KW, Jung S (2013) Microglia, seen from the CX3CR1 angle. Front Cell Neurosci 7:26. CrossRef Medline

Xing HQ, Hayakawa H, Izumo K, Kubota R, Gelpi E, Budka H, Izumo S (2009) In vivo expression of proinflammatory cytokines in HIV encephalitis: an analysis of 11 autopsy cases. Neuropathology 29:433-442. CrossRef Medline

Yuan L, Qiao L, Wei F, Yin J, Liu L, Ji Y, Smith D, Li N, Chen D (2013) Cytokines in CSF correlate with HIV-associated neurocognitive disorders in the post-HAART era in China. J Neurovirol 19:144-149. CrossRef Medline

Zheng JC, Huang Y, Tang K, Cui M, Niemann D, Lopez A, Morgello S, Chen S (2008) HIV-1-infected and/or immune-activated macrophages regulate astrocyte CXCL8 production through IL-1beta and TNF-alpha: involvement of mitogen-activated protein kinases and protein kinase $\mathrm{R}$. J Neuroimmunol 200:100-110. CrossRef Medline

Zimprich A, Biskup S, Leitner P, Lichtner P, Farrer M, Lincoln S, Kachergus J, Hulihan M, Uitti RJ, Calne DB, Stoessl AJ, Pfeiffer RF, Patenge N, Carbajal IC, Vieregge P, Asmus F, Müller-Myhsok B, Dickson DW, Meitinger T, Strom TM, et al. (2004) Mutations in LRRK2 cause autosomaldominant parkinsonism with pleomorphic pathology. Neuron 44:601607. CrossRef Medline 